\title{
KOHORT DENSITAS NYAMUK PADA FOGGING FOCUS DI DESA KEDUNGRANDU KECAMATAN PATIKRAJA KABUPATEN BANYUMAS TAHUN 2015
}

\author{
Elsa Endiyani' ${ }^{1)}$, Aris Santjaka ${ }^{2)}$ \\ Jurusan Kesehatan Lingkungan, Politeknik Kesehatan Kemenkes Semarang, \\ Jl. Raya Baturaden KM 12 Purwokerto, Indonesia
}

\begin{abstract}
Abstrak
Kepadatan nyamuk merupakan jumlah nyamuk yang berhasil ditemukan atau ditangkap dengan menggunakan aspirator, setiap luas wilayah dan waktu. Penelitian ini bertujuan untuk mengetahui densitas nyamuk sebelum pelaksanaan fogging focus dan setelah pelaksanaa fogging focus .Jenis penelitian ini observasional, Pengumpulan data secara cohort untuk mengikuti perkembangan densitas nyamuk sebelum dan sesudah pelaksanaan fogging focus di Desa Kedungrandu Kecamatan Patikraja. Populasi yaitu total populasi dengan sampel yang akan di ambil rumah dengan radius 200 meter dari titik pengukuran (rumah penderita DBD). Pengukuran dilakukan 4 kali yaitu 2 hari sebelum fogging ke-1, 3 hari setelah fogging ke-1, 3 hari setelah fogging ke-2, dan 6 hari setelah fogging ke-2. Variable pengukuran meliputi suhu, kelembaban, pencahayaan dan kecepatan angin. Analisis menggunakan uji Anova One Way dengan SPSS 20.0. Hasil penelitian diketahui bahwa densitas nyamuk 2 hari sebelum fogging ke-1 71 ekor dan 6 hari setelah fogging ke-2 24 ekor. Persentase penurunan sebesar $66,1 \%$. Hasil analisis statistik menunjukan $P$ value $=.056>\alpha 0,05$ maka Ho diterima yang berarti tidak terdapat perbedaan yang signifikan antara densitas nyamuk sebelum pelaksaan fogging dan sesudah pelaksanaan fogging. Hasil pengukuran suhu udara $25,25^{\circ} \mathrm{C}-28,75^{\circ} \mathrm{C}$, kelembaban $52 \%-76 \%$ dan pencahayaan 21,25 lux-586 lux. Kesimpulan efek Fogging focus hanya efektif selama 3 hari setelah fogging focus ke-2. Pemberantasan Sarang Nyamuk (PSN) secara rutin, dan fogging focus dapat di bandingkan efektifitasnya untuk menekan kepadatan nyamuk..
\end{abstract}

Kata kunci : Densitas Nyamuk, fogging focus

\begin{abstract}
Cohort Density Mosquito In Fogging Focus In The Village Kedungrandu Subdistrict Patikraja District Of Banyumas Year 2015. Mosquito density is the number of mosquitoes that have been found or caught with aspirator, in every area and time. This study aims to know mosquito density before and after the fogging focus.This study is observasional. And cohort data collection to follow the development of mosquito density before and after fogging focus in the Kedungrandu Village Subdistrict of Patikraja. The population is the total population with a sample to be taken home with a radius of 200 meters from the point of measurement (home patients with DHF). Measurements were performed 4 times ie 2 days before the first fogging, 3 days after the first fogging, 3 days after the second fogging, and 6 days after the second fogging. Variable measurements include temperature, humidity, lighting and wind speed. Analysis using One Way Anova test with SPSS 20.0. Results reveal that mosquito density 2 days before the first fogging 71 tails and 6 days after the second fogging 24 tails. The percentage decrease of 66.1\%. Statistical analysis showed the P value $=.056>\alpha 0.05$ then Ho is accepted, which means there are no significant differences between mosquito density before and after the implementation of fogging. The measurement results $25,25^{\circ} \mathrm{C}$ $28,75^{\circ} \mathrm{C}$ air temperature, humidity of 52\% -76\% and illumination 21,25 lux-586 lux. Fogging focus effect only effective for 3 days after the second fogging. Mosquito breeding place eradication on a regular basis, and fogging can on compare its effectiveness to suppress the mosquito density.
\end{abstract}

Keywords : Density mosquitoes, fogging focus

\section{PENDAHULUAN}

Kepadatan nyamuk adalah jumlah nyamuk yang berhasil ditemukan atau ditangkap dengan menggunakan aspirator, setiap luas wilayah dan waktu. Kepadatan nyamuk Aedes aegypti yang dapat menyebarkan penyakit demam berdarah dengue sangat dipengaruhi oleh faktor-faktor lingkungan fisik seperti curah hujan, temperatur dan kelembapan

1) Email : elsyaendiyani@yahoo.co.id

2) Email : arissantjaka@gmail.com udara (Primadatu Deswara, 2012). Kepadatan vektor di Indonesia (Indeks premis/HI) diperkirakan 20\% atau $5 \%$ di atas nilai ambang risiko penularan (Soeroso T dan Umar, 2002). Tetapi hasil penelitian di berbagai daerah menunjukan angka yang lebih tinggi. HI di Kota Palembang mencapai 44,7\% (Budiyanto A, 2008), di Jakarta Utara 27,3\% (Hasyimi M dan Soekirno M, 2008), di Simongan 
dan Manyaran (Semarang Barat) 47,3\% dan 53,49\% (Widiarti et.al, 2006).

Dalam hal pemberantasan penyakit DBD di Kabupaten Banyumas dilakukan pelaksanaan fogging focus, malathion adalah jenis insektisida yang paling sering digunakan. Berdasarkan data dari Dinas Kesehatan Kabupaten Banyumas dari tahun 2015 sampai januari 2016 telah dilakukan 41 kali pelaksanaan fogging focus yang tersebar di 36 desa/kelurahan.

Kasus DBD di Kecamatan Patikraja pada tahun 2015 terdapat 32 kasus, yang tersebar di 8 desa/kelurahan. Salah satu desa yang terdapat kasus DBD adalah Desa Kedungrandu. Desa Kedungrandu dari tahun 2011-2015 selalu terdapat kasus dan selalu dilaksanakan fogging focus sebagai penanggulangan DBD (Anonim, 2015). Pada tahun 2015 Kedungrandu terjadi 5 kasus DBD, kegiatan untuk menanggulangi terjadinya KLB demam berdarah dengue, pihak Dinas Kesehatan Kabupaten Banyumas melaksanakan fogging focus. Sebelum dan sesudah pelaksanaan fogging focus Dinas Kesehatan Kabupaten Banyumas tidak melaksanakan pengukuran densitas nyamuk sebagai evaluasi program di wilayah yang akan di lakukan fogging focus. Berdasarkan hal itu tidak dapat di ketahui dengan pasti fogging focus yang dilakukan dapat maksimal menurunkan densitas nyamuk di wilayah tersebut atau tidak. Tujuan penelitian ini adalah Mengetahui densitas nyamuk sebelum pelaksanaan fogging focus dan setelah pelaksanaa fogging focus di Desa Kedungrandu Kecamatan Patikraja tahun 2015.

\section{BAHAN DAN METODE}

Penelitian ini dilaksanakan di Desa Kedungrandu Kecamatan Patikraja yang memiliki luas wilayah \pm 421,7 Ha. Keadaan umum tanah berupa dataran rendah yang memiliki ketinggian $72 \mathrm{mdpl}$.

Subyek dalam penelitian ini adalah rumah penderita yang dilakukan fogging focus di Desa Kedungrandu Kecamatan Patikraja Kabupaten Banyumas pada radius 200 meter dengan mengukur densitas nyamuk radius 200 meter dari titik pengukuran (rumah penderita DBD) dengan melakukan survei nyamuk pada tempat istirahat (Resting).

Analisis data menggunakan analisis univariat dan analisis bivariat. Analisis univariat dilakukan untuk menjelaskan atau mendeskripsikan masing-masing variabel yaitu fogging focus dan densitas nyamuk dan membuat grafik cohort densitas nyamuksebagai dampak fogging focus. Analisis bivariat pada penelitian ini dilakukan untuk mengetahui hubungan variable independent yaitu fogging focus dengan variable dependent yaitu densitas nyamuk dan menggunakan uji statistic Anova one way untuk indikator densitas nyamuk dengan derajat kepercayaan 95\%.

\section{III.HASIL DAN PEMBAHASAN}

a. Kasus DBD di Desa Kedungrandu Kecamatan Patikraja

Data dari Puskesmas Patikraja di Kecamatan Patikraja pada tahun 2015 terdapat 32 kasus DBD. Kasus tersebut tersebar pada 8 desa dari 13 desa di Kecamatan Patikraja. Berikut merupakan jumlah kasus DBD pada tahun 2015 di Desa Kedungrandu Kecamatan Patikraja :

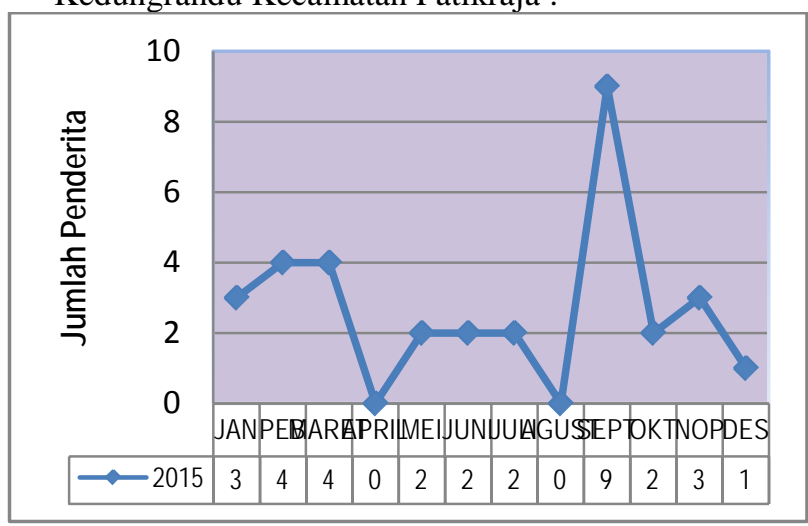

Gambar 4.1 Grafik Bulanan Kasus DBD di Desa Kedungrandu Tahun 2015

(Sumber : Data Puskesmas Patikraja Tahun 2015)

Bulan September di Desa Kedungrandu merupakan bulan dengan jumlah kasus tertinggi pada tahun 2015.Pada awal bulan September merupakan musim penghujan, musim penghujan menyebabkan tempat perindukan nyamuk Aedes aegypti bertambah banyak karena banyak bertambahnya genangan air dan tempat-tempat penampungan air yang terisi oleh air hujan. Dengan kondisi yang seperti itu nyamuk akan meletakkan telur-telurnya dan dengan kondisi lingkungan yang optimal telur akan menetas menjadi nyamuk dewasa.

b. Gambaran Pelaksanaan Fogging Focus

Fogging focus dilaksanakan di Kecamatan Patikraja pada bulan Oktober 2015 pukul 07.00 WIB di satu lokasi yaitu Desa Kedungrandu di RT 1-2 RW 3 dan RT 1-4 RW 7. Lokasi ini mengikuti kegiatan fogging focus yang dilaksanakan oleh Dinas Kesehatan Kabupaten Banyumas dengan kriteria, bila ditemukan kasus DBD lain (1 atau lebih) dan/atau ditemukan $\geq 3$ suspek/tersangka DBD serta ditemukan jentik nyamuk DBD $\geq 5 \%$ dari seluruh rumah yang diperiksa oleh pihak puskesmas.

Fogging focus dilakukan 2 kali dalam interval 1 minggu. Fogging pertama dilaksanakan pada tanggal 12 Oktober 2015 dan fogging ke dua dilaksanakan pada tanggal 19 Oktober 2015. Berikut adalah penjelasan mengenai jenis alat, dosis, dan cara pelaksanaan fogging focus :

1. Jenis Alat

Alat semprot fogging yang digunakan oleh Dinas Kesehatan Kabupaten Banyumas adalah Swing Fog Machine SN 50. Dengan kapasitas tangki insektisida 6,5 L, kapasitas untuk tangki bahan bakar 1,4 L dan berat badan 
(kosong) 8,8 kg. Diperlukan bahan bakar per jam 2 L/jam, untuk penyemprotan dengan menggunakan alat ini diperlukan waktu $\pm 2-3$ menit setiap rumah dan halaman.

Sesuai dengan cara bekerjanya alat semprot (Fog. Machine) terdapat 2 jenis alat semprot untuk yaitu Portable Thermal For Machine (Swing fog, KEF Fog, Pulls Fog, dan Dina Fog) dan ULV (Ultra Low Volume). Tetapi jenis alat yang sering digunakan adalah Swing fog karena untuk alat ini dipergunakan untuk keperluan operasi fogging dari rumah ke rumah. Prinsip kerja alat ini yakni menghasilkan fog (kabut) insektisida sebagai hasil kerja semburan gas pembakaran yang memecah larutan racun serangga sebagai hasil kerja semburan gas pembakaran yang memecah larutan insektisida tersebut menjadi drop let yang sangat halus dan berwujud kabut. Alat ini cukup berat untuk menggunakan alat ini harus mendapat pelatihan terlebih dahulu. (Dirjen P2\&PL, 1981)

Berdasarkan SNI 05-7190-2006, swing fog termasuk jenis mesin pengasap sistem pulsa jet berfungsi untuk menghasilkan dan menyemburkan asap, dioperasikan dengan cara dijinjing yang terdiri dari: tangki formulasi berisi solar bercampur insektisida, pengatur aliran (orifice), tangki bahan bakar bensin, pompa starter, karburator, ruang bakar, laras knalpot, busi, baterai dan koil. Berat keseluruhan mesin pengasap beserta perlengkapannya dalam keadaan tangki kosong yaitu maksimum 9 kg kapasitas tangki insektisida 4 - 6 L, kapasitas untuk tangki bahan bakar 1 - 2 L, konsumsi bahan bakar 1,0 - 2 L/jam. Menurut Kementerian Kesehatan RI (2012) dari berbagai studi dan pengalaman selama ini untuk rumah dan halaman didaerah urban di Indonesia memakan waktu fogging antara 2-3 menit/rumah.

2. Dosis

Insektisida yang dipakai untuk pengasapan adalah zetta sipermetrin. Perbandingan yang digunakan 0,5 zetta sipermetrin/10 L solar. Insektisida yang sering digunakan menurut Dirjen P2\&PL (1981) untuk fogging adalah jenis insektisida malathion. Odentara Sembiring (2009) mengemukakan jenis insektisida malathion mempunyai toksisitas tinggi untuk melumpuhkan serangga. Insektisida malathion termasuk golongan organofosfat, yang paling toksik diantara jenis pestisida lainnya dan sering menyebabkan keracunan terhadap manusia. Penggunaan insektisida malathion dalam waktu lama atau dipakai secara terus menerus dapat menimbulkan kekebalan nyamuk sasaran. Di daerah Istimewa Yogyakarta dan Jawa Tengah dilaporkan telah terjadi kekebalan nyamuk terhadap insektisida. Di Kuala Lumpur Malaysia dilaporkan oleh Lee, telah terjadi resistensi Aedes aegypti terhadap insektisida malathion, oleh sebab itu perlu dicari insektisida alternative yang efektif terhadap nyamuk vektor DBD.

Dinas Kesehatan Kabupaten Banyumas memilih insektisida zeta sipermetrin karena zeta sipermetrin merupakan insektisida piretroid hasil rekayasa teknologi tinggi yang ramah lingkungan. Insektisida ini bersifat kontak dan sangat efektif membuhun semut, kecoa, lalat, dan nyamuk. Kelebihan zeta sipermetrin mempunyai efek residu lebih lama, sehingga dapat menjaga lebih lama area perlakuan dari investasi hama baru, mempunyai tekanan uap rendah sehingga bahaya terhirup oleh operator relatif rendah dan untuk penggunaan yang cukup lama tidak perlu dilakukan pemeriksaan kadar cholinesterase dalam darah operatornya serta mempunyai toksisitas rendah terhadap mamalia. Dosis aplikasi yang digunakan untuk insektisida zeta sipermetrin yaitu 8-12 $\mathrm{ml} /$ liter solar (Odentara Sembiring, 2009). Dan dosis racun serangga golongan piretroid sebagai in door thermal fogging dengan konsentrasi $0,2 \%$ dalam kerosene, ternyata sangat efektif terhap Ae aegypti dalam dosis 10 gram a.i./ha sewaktu terjadi wabah di Singapura tahun 1973. (Kementerian Kesehatan RI, 2012)

3. Cara Pelaksanaan Fogging Focus

Berikut adalah tahap pelaksanaan fogging focus yang dilaksanakan oleh Dinas Kesehatan Kabupaten Banyumas :

a) Memberikan informasi kepada ketua RT/RW dan selanjutnya kepada masyarakat bahwa akan dilakukan fogging. Masyarakat diminta untuk menutup pintupintu keluar (kecuali pintu depan), jendelajendela dan menutup/mengamankan makanan serta burung-burung piaraan.

b) Ketua tim dari Dinas Kesehatan Kabupaten Banyumas membuat rencana atau pembagian tugas kepada tim petugas pengasapan yang berjumlah 7 orang.

c) Petugas pengasapan memeriksa mesinmesin swing fog yang akan dipergunakan.

d) Petugas pengasapan menyiapkan bahan, alat, dan perlengkapan fogging focus.

e) Petugas pengasapan membuat campuran zetha dengan solar dengan perbandingan yaitu 0,5 sipermetrin zetta/ $10 \mathrm{~L}$ solar.

f) Setelah itu insektisida di masukan ke dalam mesin swing fog SN 50

g) Petugas memakai APD sebelum pelaksanaan fogging seperti masker, topi 
lapangan, sarung tangan, dan sepatu lapangan.

h) Kemudian Mesin dihidupkan dan petugas siap untuk melakukan penyemprotan ke setiap rumah.

i) Petugas melakukan penyemprotan dengan cara mundur, dimulai dari bagian dalam rumah menuju keluar rumah setelah selesai pintu rumah langsung ditutup dan melanjutkan kerumah berikutnya.

Pelaksanaan fogging focus dilaksanakan oleh satu tim yang minimal berjumlah 5 orang yang terdiri dari 1 orang kepala regu dan 4 orang tenaga pelaksana. Sebelum operasi pelaksanaan fogging focus petugas membuat pemetaan dan pemberitahuan kepada masyarakat 1 hari sebelum operasi. Kemudian merencanakan jumlah bahan insektisida sesuai luas lahan yang akan dilaksanakan fogging focus. Pada saat hari pelaksanaan operasi fogging focus, memberikan informasi kepada ketua RW/RT yang akan dilakukan fogging, kepala regu membagian tugas kepada masingmasing petugas fogging, petugas memeriksa mesin-mesin swing fog dan membuat campuran insektisida kemudian memasukan kedalam mesin-mesin yang akan digunakan. Petugas lapangan memakai alat/perlengkapan yang sudah disedikan dan setelah selesai pengasapan petugas mengisi formulir OP-1. Prosedur fogging yang dilakukan Dinas Kesehatan Kabupaten Banyumas sudah baik akan tetapi terdapat rumah yang tidak dilakukan fogging karena penghuninya tidak ada. (Dirjen P2\&PL, 1981)

Alat pelindung diri yang digunakan untuk pelaksanaan fogging yaitu sepatu boot, sepatu kanvas, baju terusan lengan panjang dan celana panjang (coverall), topi, sarung tangan, apron/celemek, pelindung muka, dan masker. Fogging yang dilakukan di dalam rumah harus dimulai dari ruangan yang paling belakang, jendela dan pintu ditutup kecuali pintu depan untuk keluar masuk petugas sedangkan untuk fogging di luar rumah tabung pengasap harus searah dengan arah angin, dan petugas berjalan mundur. Penghuni rumah selama rumah di fog, semua penghuni supaya berada diluar, Setelah fog dalam ruangan menghilang baru para penghuni boleh masuk kembali. (15-30 menit setelah fogging). (Kememnterian Kesehatan RI, 2012)

c. Kondisi Lingkungan Fisik

Hasil pengukuran suhu udara, kelembaban, intensitas cahaya, dan kecepatan angin adalah sebagai berikut :

1. Suhu, Kelembaban dan Intensitas Cahaya Penelitian ini mengukur beberapa faktor lingkungan fisik yaitu suhu, kelembaban, intensitas cahaya. Pengukuran dilakukan di 20 rumah responden, antara pukul 07.00 WIB sampai 12.00 WIB dengan mengunakan alat thermohigrometer dan luxmeter diruang tamu. Hasil pengukuran suhu, kelembaban dan pencahayaan adalah sebagai berikut :

Tabel 4.5 Rata-rata Hasil Pengukuran Kondisi Lingkungan Fisik di Rumah Responden

\begin{tabular}{llrrr}
\hline No & Indikator & Min & Max & $\begin{array}{c}\text { Rata- } \\
\text { Rata }\end{array}$ \\
\hline 1. & Suhu $\left({ }^{\circ} \mathrm{C}\right)$ & 25,25 & 28,75 & 27,16 \\
\hline 2. & $\begin{array}{l}\text { Kelembaban } \\
(\%)\end{array}$ & 52 & 76 & 63,5 \\
\hline 3. & $\begin{array}{l}\text { Intensitas } \\
\text { Cahaya (Lux) }\end{array}$ & 21,25 & 586 & 181 \\
\hline
\end{tabular}

(Sumber : Data Terolah)

Suhu rata-rata hasil pengukuran di rumah responden adalah $27,16^{\circ} \mathrm{C}$, suhu terendah $25,25^{\circ} \mathrm{C}$ sedangkan untuk suhu tertinggi yaitu $28,75^{\circ} \mathrm{C}$. Iskandar, dkk (1985) menyatakan bahwa pada umumnya nyamuk akan meletakkan telurnya pada temperature sekitar $20^{\circ} \mathrm{C}-30^{\circ} \mathrm{C}$. Toleransi terhadap suhu tergantung pada spesies nyamuk. Menurut WHO (1972) dalam telur nyamuk tampak telah mengalami embriosasi lengkap dalam waktu 72 jam dalam temperature udara $25^{\circ} \mathrm{C}$ $30^{\circ} \mathrm{C}$. menurut Yotopranoto, dkk (1998) dijelaskan bahwa rata-rata suhu optimum untuk pertumbuhan nyamuk adalah $25^{\circ} \mathrm{C}$ $27^{\circ} \mathrm{C}$ dan pertumbuhan nyamuk akan terhenti sama sekali bila suhu kurang dari $10^{\circ} \mathrm{C}$ atau lebih dari $40^{\circ} \mathrm{C}$.

Kelembaban rata-rata hasil pengukuran di rumah responden adalah 63,5 dan kelembaban terendah 52\% sedangkan untuk kelembaban tertinggi 76\%. Menurut Mardihusono (1988) disebutkan bahwa kelembaban udara yang berkisar 81,5\%-89,5\% merupakan kelembaban yang optimum untuk proses adaptasi nyamuk. Menurut Aris Santjaka (2013) nyamuk umumnya menyukai kelembaban diatas 60\% karena pada kelembaban rendah terjadi penguapan tinggi pada tubuh nyamuk, sehingga mekanisme penguapan tidak terjadi, dampaknya nyamuk akan kehilangan cairan cukup besar sehingga mengalami kekeringan cairan.

Intensitas cahaya rata-rata hasil pengukuran di rumah responden adalah 181 lux, intensitas cahaya terendah 21,25 lux dan intensitas cahaya tertinggi 586 lux. Menurut Depkes RI (2010) Intensitas cahaya/pencahayaan yang sesuai untuk kehidupan nyamuk yaitu $<60$ lux, cahaya merupakan faktor utama yang mempengaruhi nyamuk beristirahat pada suatu tempat intensitas cahaya yang rendah dan kelembaban yang tinggi merupakan kondisi yang baik bagi nyamuk intensitas cahaya merupakan faktor terbesar yang 
mempengaruhi aktivitas terbang nyamuk. Hasill pengukuran rata-rata intensitas cahaya yang paling tinggi adalah 586 lux, intensitas cahaya yang tinggi dipengaruhi oleh cahaya buatan seperti lampu, bohlam dan cahaya buatan seperti sinar matahari.

2. Kecepatan Angin

Pengukuran kecepatan angin dilakukan pada saat pelaksanaan fogging focus pertama dan kedua. Pengukuran dilakukan secara berkala selama 2 kali. Pengukuran pertama pada saat fogging pertama dan pengukuran kedua pada saat fogging kedua. Pengukuran dilakukan diluar ruangan pada saat kegiatan fogging berlangsung menggunakan alat anemometer. Jumlah rata-rata dari kedua pengukuran tersebut yang dapat di lihat dalam tabel 4.6 sebagai berikut :

Tabel 4.6 Hasil Pengukuran Kecepatan Angin

No Titik Kecepatan Angin (m/s)
Pengukuran Fogging ke-1 Fogging ke-2

\begin{tabular}{lcc}
\hline 1. Lapangan & 1,4 & 1,2 \\
\hline 2. Gang 1 & 1,1 & 0,5 \\
\hline 3. Gang 2 & 0,5 & 1 \\
\hline 4. Gang 3 & 1,3 & 0,7 \\
\hline 5. Gang 4 & 1,2 & 1,2 \\
\hline 6. Gang 5 & 0,2 & 1 \\
\hline 7. Gang 6 & 1,2 & 0,3 \\
\hline Rata-Rata (m/s) & 0,7 & 0,84 \\
\hline Rata-Rata $(\mathrm{km} / \mathrm{jam})$ & 2,52 & 3,024 \\
\hline
\end{tabular}

(Sumber : Data Terolah)

Hasil pengukuran kecepatan angin rata-rata pada fogging pertama yaitu 2,52 km/jam dan pada fogging kedua 3,024 km/jam hasil itu menunjukan angin tidak terlalu kencang dan dapat dilaksanakan kegiatan fogging. Fogging dilaksanakan pada pukul 07.00-12.00 WIB dan pukul 15.00-17.00 WIB, waktu operasi pada pagi atau sore hari dalam keadaan udara tidak terlalu panas/kurang dari $28^{\circ} \mathrm{C}$ dan angin cukup tenang, maximum kecepatan angin 20 $\mathrm{km} / \mathrm{jam}$. Beberapa tes menunjukkan bahwa jarak sembur yang paling baik adalah 80-100 meter dangan kecepatan angin 10-15 km/jam. Pada kecepatan angin lebih dari $20 \mathrm{~km} / \mathrm{jam}$ fogging supaya dihentikan saja. (Kementrian Kesehatan, 2012)

Kecepatan angin secara tidak langsung akan mempengaruhi penguapan air dan suhu udara serta pada penyebaran pasif nyamuk. Kecepatan angin 11-14 meter/detik atau 22-28 knot maka akan menghambat perkembangan nyamuk sehingga penyebaran vektor menjadi terbatas. (Pratiwi Handayani, 1999)

d. Hasil Pengukuran Densitas Nyamuk

Pengukuran densitas nyamuk yang peneliti lakukan dengan cara menarik garis lurus 200 meter ke arah utara, selatan, barat, dan timur dari 1 indeks kasus. Pengukuran densitas nyamuk yang dilakukan peneliti adalah dengan cara berkala yaitu pada saat 2 hari sebelum pelaksanaan fogging focus I dilaksanakan tanggal 10 Oktober 2015 pukul 07.00 WIB-12.00 WIB, pada saat 3 hari setelah fogging focus I tanggal 14 Oktober 2015 pukul 07.00 WIB-12.00 WIB, pada saat 3 hari setelah fogging focus II tanggal 21 Oktober 2015 pukul 07.00 WIB-12.00 WIB, pada saat 6 hari setelah fogging focus II tanggal 25 Oktober 2015 pukul 07.00 WIB-12.00 WIB. Pengukuran dilakukan dengan melakukan penangkapan nyamuk di dalam rumah dengan waktu 10-20 menit dengan menggunakan alat aspirator, paper cup, dan senter kemudian data pengukuran dimasukan ke dalam form. Nyamuk yang tertangkap tidak dilakukan identifikasi sehingga tidak dapat mengetahui jenis nyamuk yang mendominasi di wilayah penelitian. Berikut adalah gambar grafik hasil pengukuran densitas nyamuk :

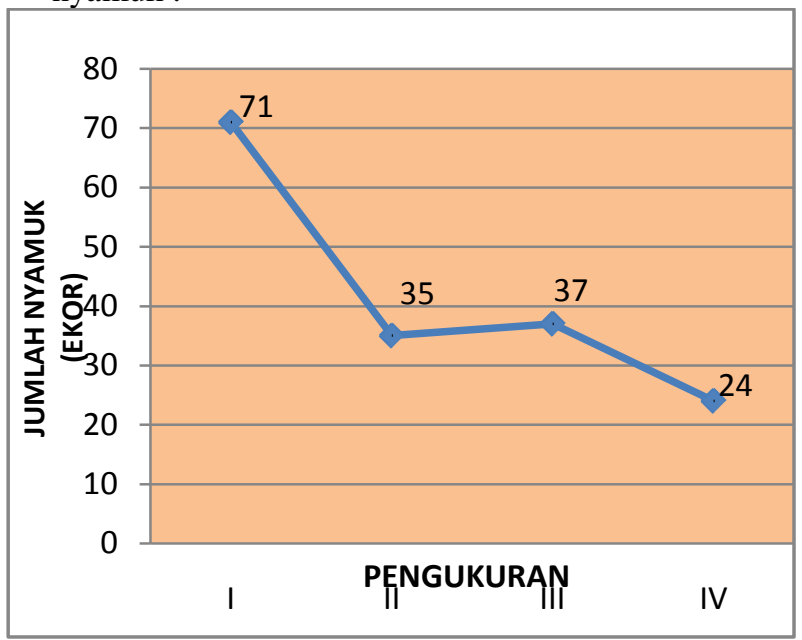

Gambar 4.2 Grafik Kohort Densitas Nyamuk (Sumber : Data Pengukuran Densitas Nyamuk)

Untuk mengetahui kepadatan populasi nyamuk di suatu lokasi dapat dilakukan beberapa survei di rumah yang dipilih secara acak. Survei nyamuk dilakukan dengan cara penangkapan nyamuk yang hinggap di dinding dalam rumah yang sama masing-masing selama 20 menit per rumah. (Dirjen PP\&PL, 1994)

Data dari hasil penangkapan nyamuk yang dilakukan dari 2 hari sebelum fogging ke-1 (pengukuran I) sampai 6 hari setelah fogging ke-2 (pengukuran IV) mengalami penurunan, jumlah nyamuk pada pengukuran 2 hari sebelum fogging ke-1 (pengukuran I) sebanyak 71 ekor dan 3 hari setelah fogging ke-1 (pengukuran II) sebanyak 35 ekor. Penurunan pengukuran ke-1 dan pengukuran ke-2 yaitu 36 ekor atau 50,7 \%, hal itu menunjukan setelah fogging siklus ke-1 terdapat penurunan yang drastis. Kemudian pengukuran 2 hari sebelum fogging ke-1 (pengukuran I) dengan 3 hari setelah fogging ke-2 (pengukuran III) mengalami penurunan lagi sebanyak 34 ekor atau 47,8 \%. Penurunan juga terjadi pada pengukuran 2 hari sebelum fogging ke-1 (pengukuran I) dan 6 hari setelah fogging ke- 
2 (pengukuran IV) yaitu sebanyak 47 ekor atau 66,1 \%. Tapi pengukuran 3 hari setelah fogging ke-1 (pengukuran II) dan 3 hari setelah fogging ke-2 (pengukuran III) mengalami kenaikan yang awalnya jumlah nyamuk 35 ekor menjadi 37 ekor (gambar 4.2).

Penyakit DBD ditularkan oleh nyamuk Aedes aegypti dan merupakan penyakit ekologis yaitu penyakit yang sangat dipengaruhi oleh kondisikondisi lingkungan yang memungkinkan nyamuk untuk berkembang biak. Faktor lingkungan yang berpengaruh pada kepadatan nyamuk adalah lingkungan fisik seperti suhu, kelembaban, curah hujan, angin, ketinggian dan pencahayaan (Sri Wahyu Fitria, skripsi 2015).

Jumlah nyamuk yang tinggi pada pengukuran 2 hari sebelum fogging ke-1 dipengaruhi kondisi lingkungan yang optimum untuk pertumbuhan nyamuk. Setelah dilaksanakan fogging jumlah nyamuk menurun hingga 6 hari setelah fogging ke-2. Jumlah nyamuk meningkat pada pengukuran 3 hari setelah fogging ke-2. Meningkatnya jumlah nyamuk karena jentik yang masih terdapat dilingkungan sekitar akan tumbuh menjadi nyamuk dewasa. Menurut Ginanjar Genis (2007) waktu pertumbuhan nyamuk memerlukan waktu \pm 7 hari, Jentik dari instar satu sampai empat yang belum terbunuh dapat menjadi nyamuk dewasa, perkembangan jentik dari instar satu hingga empat memerlukan waktu 5 hari. Setelah mencapai instar ke empat, larva berubah menjadi tidak aktif (dorman). Pupa bertahan selama 2 hari sebelum akhirnya nyamuk dewasa keluar dari pupa. Rentang waktu dari pengukuran 3 hari sebelum fogging ke-1 ke pengukuran 3 hari setelah fogging ke-2 adalah 8 hari, dalam rentang waktu tersebut perkembangan nyamuk dapat terjadi.

Pelaksanaan fogging yang tidak merata, memungkinkan semua nyamuk dewasa belum terbunuh. Dari 6 RT yang dilakukan fogging terdapat rumah yang tidak dilakukan fogging karena penghuni rumah sedang pergi, terdapat orang sakit dan bayi, ada rumah yang kosong atau tidak ditempati dan beberapa rumah bagian belakang tidak dilakukan fogging oleh petugas. Karena hal itu densitas nyamuk dapat meningkat pada 3 hari setelah fogging ke-1.

Nyamuk Aedes aegypti dapat mengalami resistensi terhadap insektisida dan dapat mempengaruhi densitas nyamuk. Aedes aegypti dilaporkan resisten terhadap insektisida sipermetrin di Brazil, dan terhadap deltametrin dan permetrin di Bandung, Palembang dan Surabaya serta Semarang, Indonesia. Studi di Mae Sat dan Phatthalung, Thailand, membuktikan bahwa Aedes aegypti resisten terhadap permetrin, sedangkan di Bangkok dan Nontthaburi resisten terhadap deltametrin dan alfasipermetrin. Resistensi serangga terhadap insektisida umumnya terjadi setelah masa penggunaan 2-20 tahun. Insektisida piretroid yag paling lama (lebih dari 10 tahun) dan sering digunakan di Jawa Tengah adalah jenis sipermetrin.

e. Uji Statistik

Data yang diperoleh dari pengamatan kemudian dianalisis menggunakan uji Anova One Way untuk mengetahui perbedaan densitas nyamuk pada 2 hari sebelum fogging ke-1, 3 hari setelah fogging ke-1, 3 hari setelah fogging ke-2, dan 6 hari setelah fogging ke-2. Dari uji Anova One Way tersebut didapatkan hasil sebagai berikut :

Tabel 4.7 Hasil Uji Beda Densitas Nyamuk Sebelum dan Setelah Pelaksanaan Fogging focus

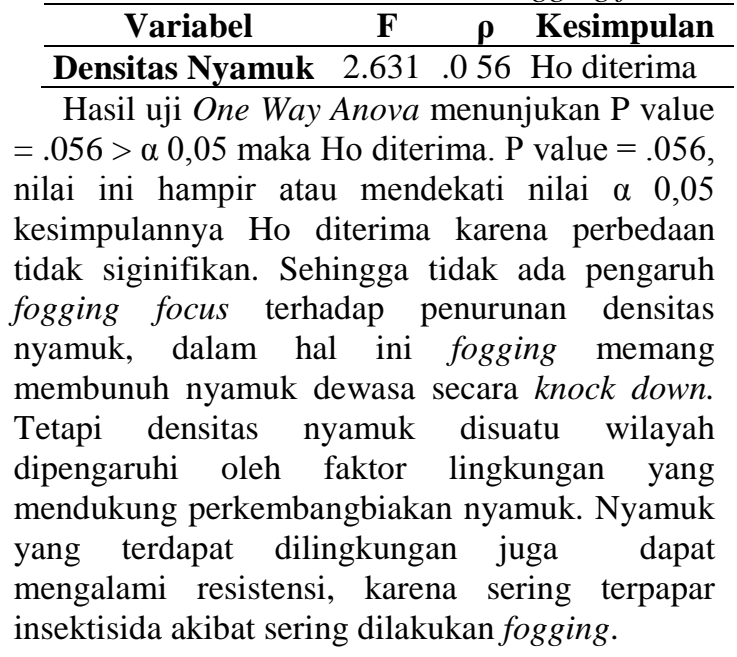

\section{IV.KESIMPULAN}

Densitas nyamuk 2 hari sebelum pelaksanaan fogging focus focus siklus ke-1 tinggi, sebanyak 71 ekor dan 6 hari setelah fogging focus siklus ke-2 mengalami penurunan sebanyak 24 ekor. Persentase penurunan sebesar $66,1 \%$, dapat disimpulkan secara nyata pelaksanaan fogging focus dapat menurunkan densitas nyamuk 6 hari setelah pelaksanaan fogging focus siklus ke-2.

Kondisi lingkungan fisik di Desa Kedungrandu berpotensi sebagai tempat perkembangbiakan nyamuk Aedes sp. dengan hasil pengukuran suhu rata-rata $25,25^{\circ} \mathrm{C}-28,75^{\circ} \mathrm{C}$, kelembaban rata-rata $52 \%-76 \%$ dan pencahayaan rata-rata 21,25 lux-586 lux.

Cara pelaksanaan fogging focus yang dilakukan oleh Dinas Kesehatan Kabupaten Banyumas sudah baik. Jangkauan yang ditentukan oleh Dinas Kesehatan Banyumas yaitu 200 meter dari rumah penderita dan mesin yang digunakan yaitu swing fog SN 50 dengan perbandingn dosis 0,5 zetta sipermetrin/10 L solar efektif membunuh vektor DBD.

Grafik kohort densitas nyamuk secara nyata mengalami penurunan, dapat disimpulkan pelaksanaan fogging focus berpengaruh terhadap penurunan densitas nyamuk. 
Hasil uji statistik menunjukan uji homogenitas didapatkan sig $=.267>\alpha 0,05$ maka datanya homogen. Hasil uji One Way Anova menunjukan P value $=.056>\alpha 0,05 . \mathrm{P}$ value $=.056$, nilai ini hampir atau mendekati nilai $\alpha \quad 0,05$ kesimpulannya Ho diterima karena perbedaan tidak siginifikan. Sehingga secara statistik tidak ada pengaruh fogging focus terhadap penurunan densitas nyamuk.

\section{DAFTAR PUSTAKA}

Bagyono, Tuntas. 2013. Kunci Praktis Untuk Metodologi Penelitian Kesehatan PromotifPreventif. Yogyakarta : Penerbit Ombak

Budiyanti, A. 2005. Studi Indeks Larva Nyamuk Aedes Aegypti dan Hubungannya dengan PSP Masyarakat tentang Penyakit DBD di Kota Palembag Sumatera Selatan .(Online).Tersedia:http://www.Libangdepkes.g o.id/lokbaturaja/dwnload/artikel\%20\%kontain er\%20\%202005 (24 Januari 2015)

Depkes RI. 1981. Penanggulangan Fokus Demam Berdarah. Jakarta : Direktorat Jenderal P3M

.1994. Petunjuk Teknis Pemberantasan Nyamuk Penular Penyakit Demam Berdarah Dengue. Jakarta : Ditjen PP dan PL

. 2001. Pedoman Ekologi dan Aspek Perilaku Vektor. Jakarta : Ditjen PP dan PL

- 2005. Pencegahan dan Pemberantasan Demam Berdarah Dengue di Indonesia. Jakarta : Kementerian Kesehatan RI

. 2007. Modul Pelatihan bagi Pengeolaan Program Pengendalian Penyakit Demam Berdarah Dengue di Indonesia. Jakarta : Ditjen PP dan PL.

. 2007. Survai Entomologi Demam Berdarah Dengue. Jakarta : Ditjen PP dan PL

- 2011. Modul Pengendalian Demam Berdarah Dengue. Jakarta : Ditjen PP dan PL.

. 2011. Tata Laksana DBD. (Online). Tersedia:http://www.depkes.go.id/downloads/ Tata\%20Laksana \%20DBD.pdf (27 Januari 2016)

. 2015. Profil Kesehatan Indonesia 2014. Jakarta : Kementerian Kesehtan RI

Deswara, Primadatu. 2012. Hubungan Kepadatan Nyamuk Aedes aegypti di Dalam Rumah Dengan Angka Kesakitan Demam Berdarah Dengue (DBD) pada Masyarakat di Kota
Metro Provinsi Lampung. Skripsi Sarjana pada FKM UI

Dinkes Jawa Tengah. 2012. Profil Dinas Kesehatan Jawa Tengah tahun 2012. Semarang : Dinas Kesehatan Jawa Tengah

Dinkes Banyumas. 2014. Profil Dinas Kesehatan Kabupaten Banyumas tahun 2014. Banyumas : Dinas Kesehatan Banyumas

Direktorat Jenderal Pengendalian Penyakit dan Penyehatan Lingkungan. 2012. Pedoman Penggunaan Insektisida (Pestisida) Dalam Pengendalian Vektor. Jakarta : Kementerian Kesehatan Republik Indonesia

Ginanjar, Genis. 2007. Demam Berdarah. Yogyakarta : B-first

Handayani, Lestari dan Suharmiati. 2007. Tanaman Obat dan Ramuan Tradisional Untuk Mengatasi Demam Berdarah Dengue. Jakarta : PT Agromedia Pustaka

Harnowo. 2005. Evaluasi Pelaksanaan Fogging Fokus Pengendalin Vektor Demam Berdarah Degue (DBD) di Kabupaten Kebumen. Skripsi Sarjana pada UNDIP Semarang

Hastono, S. P. 2006. Analisis Data. FKMUI. Jakarta

Hasyimi M. 1993. Aedes Aegypti Sebagai Vektor DBD Berdasarkan Pengamatan di Alam, Jakarta : Media Litbangkes Vol. III No. 2

Iskandar, A. 1985. Pemberantasan Serangga dan Binatang pengganggu Akademi Penilik Kesehatan Teknologi Sanitasi (APK-TS). Jakarta : Pusat Pendidikan Tenaga Kesehatan, Departemen Kesehatan RI

Nadesul, H. 2007. Cara Mudah Mengalahkan Demam Berdarah. Jakarta : Kompas Media Nusantara

Notoatmodjo, Soekidjo. 1993. Metode Penelitian Kesehatan. Jakarta : Melton Putra Offset

Peraturan Menteri Kesehatan. 2010. Jenis Penyakit Menular Tertentu yang Dapat Menimbulkan Wabah dan Upaya Penanggulangan. Jakarta : Permenkes

Santjaka, Aris. 2013. Malaria Pendekatan Model Kausalitas. Yogyakarta : Nusa Medika

Sayono, dkk. 2011. Pengaruh Modifikasi Ovitrap Terhadap Jumlah Nyamuk Aedes yang Tertangkap. Tesis pada UNDIP Semarang 
Setiyawan, Nunung Cahyanto. 2010. Tinjauan Pelaksana Program Pemberantasan Vektor Penyakit Demam Berdarah Dengue (DBD) di Wilayah Kerja Puskesmas I Cilacap Utara Kabupaten Cilacap. Karya Tulis Ilmiah pada Jurusan Kesehatan Lingkungan Purwokerto Poltekkes Kemenkes Semarang

Soeroso T., Umar IA. 2002. Epidemiologi dan Penanggulangan Penyakit Demam Berdarah Dengue (DBD) di Indonesia Saat ini. Jakarta : Balai Penerbit FK UI

Suhendro, dkk. 2006. Buku Ajar Ilmu Penyakit Dalam. Jakarta : Balai Penerbit FKUI

Undang-undang Republik Indonesia. 1984. Wabah Penyakit Menular. Jakarta : Undang-undang Republik Indonesia
WHO, 2005. Pencegahan dan Pengendalian Dengue dan Demam Berdarah Dengue. Jakarta : EGC

Widiarti, Boewono DT., dkk. 2006. Deteksi Virus Dengue Berhubungan dengan Kejadian Demam Berdarah Dengue (DBD) di Kelurahan Ploso Kecamatan Pacitan. Skripsi Sarjana pada FIK UMS

Widigdo. 2014. Kepadatan dan Parousitas Aedes sp. Sebagai Vektor DBD di Kelurahan Teluk Purwokerto Selatan. Skripsi Sarjana pada FB Unsoed

World Health Organization. 2008. Dengue and Dengue Hemmoragic Fever. (Online). Tersedia:http://www.who.int/mediacentre/fact sheets/fs117/en/ (27 Januari 2016) 